\title{
SIMBOLISME DALAM TRADISI KATAM KAJI MASYARAKAT PAUH NAGARI KAMANG MUDIAK KABUPATEN AGAM
}

\author{
Gusnanda \\ UIN Imam Bonjol Padang \\ E-mail: eljambaki46@gmail.com
}

\begin{abstract}
Abstrak
Masyarakat muslim di Indonesia memiliki keunikan dan keistimewaan tersendiri dalam mempraktikkan ajaran agamanya. Termasuk tentang bagaimana cara memotivasi anak-anak untuk belajar al-Qur'an, seperti yang terdapat dalam tradisi Katam Kaji masyarakat Pauh. Tidak hanya itu, dalam tradisi tersebut terkandung juga nilai-nilai budaya dan ajaran Islam yang diekspresikan dalam bentuk simbolik dan praktik. Keduanya memiliki makna dan fungsi tersendiri bagi masyarakat setempat. Makna simbolik itu terdapat dalam atribut yang digunakan ketika acara berlangsung, seperti: pakaian kebesaran, gelar adat, dan mushaf al-Qur'an. Sedangkan makna praktik yang menjadi esensi dari tradisi ini terkandung dalam setiap interaksi dan komunikasi yang terbangun selama acara berlangsung.
\end{abstract}

Kata Kunci: Katam Kaji, Simbolisme, Makna, Nilai.

\section{Pendahuluan}

Sebaik-baik umat Islam adalah mereka yang belajar al-Qur'an dan mengajarkannya pada orang lain. Kirakira begitulah isi dari sugesti dan motivasi yang pernah disampaikan Rasul SAW agar umatnya mau membaca dan mempelajarI al-Qur'an. ${ }^{1}$ Terdapat banyak sekali dalil terkait persoalan ini yang dapat ditemukan dalam berbagai kitab hadis.

Akibat dari hadis-hadis tersebut muncullah berbagai metode dan pengajaran dalam membaca dan

${ }^{1}$ Hadis ini diterima dari Usman ibn 'Affan bahwa Rasul SAW pernah bersabda: خير ,كم من تعلم القران و علمه yang artinya sebaik-baik kalian adalah yang mempelajari al-Qur'an dan mengajarkannya. Lihat: Muhammad bin Ismail al-Bukhary dalam Shahih al-Bukhariy kitab Fadhail al-Qur'an Nomor. 4639. mempelajari ayat al-Qur'an. Bahkan, akhir-akhir ini bermunculan lembagalembaga tahfiz yang menjanjikan pesertanya mampu meghafal al-Qur'an dalam hitungan jam. Jika dianalisis secara kritis agaknya fenomena ini hanya sebatas jual beli jasa dengan pertimbangan untung rugi. Jika demikian, maka cara seperti itu tidak baik untuk dilestarikan.

Sebetulnya, dalam warisan budaya bangsa terdapat beberapa tradisi untuk mendidik dan mengajarkan anak-anak membaca alQur'an yang mesti dipertahankan. Tradisi tersebut berkembang di kampung-kampung, di mana masyarakatnya masih bercorak tradisionalis. Misalnya, Ternate menyebutnya dengan Mappanre Temme'. Ini adalah tradisi khataman alQur'an bagi orang yang sudah tamat 
mengaji. ${ }^{2}$ Barangkali tradisi serupa banyak juga yang berkembang di daerah lain dengan istilah yang beragam namun belum sempat terdokumentasikan dalam bentuk hasil penelitian. Dalam tulisan ini, penulis ingin menguraikan tradisi serupa, yakni tradisi Katam Kaji yang berkembang di wilayah Barat Indonesia, tepatnya di Jorong Pauh Nagari Kamang Mudiak Kecamatan Kamang Magek Kabupaten Agam Sumatera Barat.

Katam Kaji merupakan cara masyarakat mengajarkan dan memotivasi anak-anaknya untuk membaca al-Qur'an. Tradisi ini juga menjadi sarana dalam menanamkan nilai-nilai ajaran agama. Sebagaimana diketahui, kebiasaan beragama masyarakat seringkali menggunakan sistem simbol dan setiap rangkaian simbol tersebut memiliki makna tertentu. Begitu juga dalam tradisi Katam Kaji di Pauh Kamang Mudiak yang secara simbolis mengandung pesan-pesan luhur dalam membangun kehidupan sosial masyarakatnya. Tulisan ini selanjutnya akan berusaha mengungkap makna apa yang terkadung dalam tradisi Katam Kaji tersebut.

\section{Pespektif Penelitian}

Penelitian ini adalah penelitian field reseacrh dengan memfokuskan kajian pada bagaimana masyarakat Pauh memaknai tradisi Katam Kaji. Penelitian ini bersifat deskriptif analisis dengan menggunakan pendekatan fenomenologi sebagai pisau analisisnya. Untuk memperoleh data, penulis melakukan rangkaian metode

${ }^{2}$ Lihat: Chaerul Mundzir, "Nilai-Nilai Sosial dalam Tradisi Mappenre Temme' di Kecamatan Tenete Kabupaten Barru", Jurnal Rihlah, Vol. I, No. 2 Tahun. 2014, h. 70. pengambilan data, mulai dari wawancara, observasi dan dokumentasi. Adapun dalam melakukan wawancara penulis menggukan metode snowball sampling. Sementara yang diwawancarai adalah setiap elemen masyarakat, seperti: pemangku kepentingan, ninik-mamak, alim ulama, dan cadiak pandai. Semua elemen masyarakat ini menjadi sumber data primer sedangkan sumber data sekundernya adalah buku-buku yang relevan dengan masalah ang dikaji.

\section{Katam Kaji: Makna dan Persepsi Masyarakat Pauh}

Sebelum penulis menguraikan satu-satu persatu bagaimana masyarakat Pauh memaknai dan apa yang membuat mereka melestarikan tradisi Katam Kaji, ada baiknya dijelaskan terlebih dahulu tentang falsafah hidup yang mendasari akititas sosial keagamaan masyarakatnya. Menurut Mukhtar Dt. Mangguang bahwa falsafah hidup masyarakat Pauh adalah "Adat Basandi Syarak, Syarak Basandi kitabullah (ABS SBK)". Maksudnya, adat budaya di Minangkabau khususnya di daerah Pauh berdasarkan pada syari'at Islam yang bersumber dari al-Qur'an dan Sunah. Dalam pepatah lain juga disebutkan bahwa, "syarak mangato, adat mamakai”. Pepatah ini memiliki pengertian di mana agama menjadi standar terhadap segala bentuk akitivitas sosial-budaya masyarakat. ${ }^{3}$

Masyarakat Pauh merupakan masyarakat yang masih menjaga nilainilai adat dan ajaran agama mereka dalam kehidupan sehari-harinya. Ketaatan mereka kepada ajaran agama

${ }^{3}$ Mukhtar Dt. Mangguang, Tokoh Masyarakat, Wawancara Langsung, Pauh 13 November 2015. 
tersebut terlihat dengan tingginya keinginan dalam menerapkan nilai-nilai ajaran Islam, baik dalam bentuk normatif maupun dalam bentuk akulturasi budaya. Di antaranya adalah dengan melestarikan tradisi Katam Kaji setiap tahunnya. ${ }^{4}$ Tradisi ini merupakan sebuah perayaan santri ketika sudah menamatkan pendidikan agama atau "mengaji" di surau, TPA, atau Madrasah Diniyah Awwaliyah (MDA).

Tradisi Katam Kaji merupakan pengamalan masyarakat tentang bagaimana membumikan nilai-nilai alQur'an sehingga syiar Islam hidup di tengah masyarakat. Masyarakat Pauh memandang adanya Katam Kaji menjadi wujud dan manifestasi dari rumusan budaya Minangkabau tentang "Adat Basandi Syarak, Syarak Basandi Kitabullah". Dalam ranah yang lain, hal ini kemudian juga menjadi ideologi masyarakat Minang dalam mengaktualisasikan ajaran agama mereka. Oleh karena itu, dengan melestarikan tradisi ini berarti masyarakat Pauh telah menjalankan dan memperkuat falsafah hidup mereka sebagai masyarakat Minangkabau. ${ }^{5}$

Senada dengan itu, Bardas Samnil, selaku tokoh agama yang tertua di Pauh mengatakan bahwa Katam Kaji merupakan tradisi kuno yang turun temurun dilakukan. Dengan demikian tradisi ini harus terus dilestarikan dari generasi ke generasi. Menurutnya, tradisi ini juga merupakan bagian dari syiar Islam. Secara teologis, tradisi ini memang tidak ditemukan pada zaman Nabi Muhammad SAW. Akan tetapi, pada prinsipnya sudah dipraktikkan sejak

\footnotetext{
${ }^{4}$ Ahmad Latif Dt. Sami', Niniak Mamak Jorong Pauh, Wawancara Langsung, Pauh 20 Desember 2015. ${ }^{5}$ Ibid.,
}

awal era perkembangan Islam dalam bentuk dan skala yang berbeda. ${ }^{6}$ Prinsip yang dimaksud di sini adalah bagaimana membuat "ghirah" atau semangat anak-anak maupun orang dewasa untuk mencintai al-Qur'an dan gemar membacanya. ${ }^{7}$

Anwar selaku Wali Jorong Pauh juga menuturkan bahwa tradisi Katam Kaji bagi masyarakat Pauh memberi pengaruh terhadap sikap mental dan perilaku para generasi muda mereka untuk lebih Islami dan menjaga normanorma Islam. Para peserta yang telah mengikuti tradisi Katam Kaji berarti mereka telah memahami ajaran agama sedikit banyaknya. Seadainya mereka tidak mendalami ilmu agama dan tidak mengerti dengan ajaran agamanya

${ }^{6}$ Pandangan informan ini jika dirujuk pada kitab-kitab hadis ditemukan banyak riwayat tentang bagaimana Rasul SAW menjelaskan keutamaan al-Qur'an sehingga umat Islam diperintahkan untuk membaca, menghafal, dan mentadabburi isi al-Qur'an. Salah satunya dapat dilihat dari hadis yang diriwayatkan imam al-Bukhary dalam kitab Shahihnya, yakni sebagai berikut:

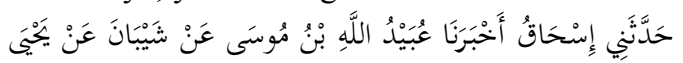

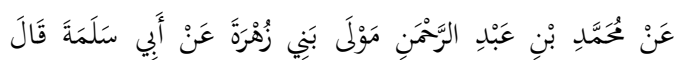

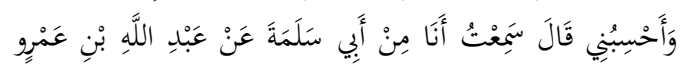

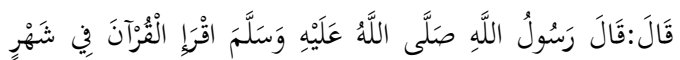

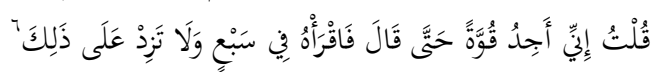
Artinya: "Ishaq menceritakan pada kami, 'Ubaidullah bin Musa mengkhabarkan pada kami, dari Syaiban dari Yahya, dari Muhammad bin 'Abdul Rahman Maula bani Zuhrah, dari Abi Salamah ia berkata: dari 'Abdullah bin 'Amr ia berkata, Rasul SAW bersabda: Bacalah (khatamkanlah) Al Quran dalam sebulan." 'Abdullah bin 'Amr lalu berkata, "Aku mampu menambah lebih dari itu." Beliau pun bersabda, "Bacalah (khatamkanlah) Al Qur'an dalam tujuh hari, jangan lebih daripada itu"' (H.R. Bukhari).

${ }^{7}$ Bardas Samnil, Imam Mesjid Jami'

Pauh, Wawancara Langsung, Pauh 13 November 2015. 
sendiri tentu akan menghasilkan karakter remaja dan pemuda yang jauh dari nilai-nilai agama Islam. ${ }^{8}$

Masyarakat Pauh sangat antusias dengan acara Katam Kaji. Hal ini terbukti ketika setiap kali diadakannya tradisi Katam Kaji, mereka berbondong-bondong untuk menghadirinya. Membaca al-Quran adalah kewajiban dan bernilai pahala. Namun, tidak semua orang bersemangat dan mau membaca alQuran dengan berbagai alasan, seperti kesibukan dan lain-lain. Tradisi ini berperan dalam memberikan semangat membaca al-Quran kepada masyarakat. Semangat itu ditularkan melalui acara yang diadakan dengan meriah agar masyarakat menjadi tertarik untuk membaca al-Quran. Atau, paling tidak merasa terpanggil untuk menyerahkan anaknya belajar mengaji al-Quran ke surau, TPA, atau MDA. ${ }^{9}$

Peserta Katam Kaji adalah pihak yang langsung merasakan bagaimana nilai-nilai dari pelaksanaan Katam Kaji tersebut. Tradisi ini membuat mereka saling berkompetisi dalam meraih prestasi dalam membaca al-Qur'an dengan baik dan benar. Hal yang menjadi penting adalah mereka memperoleh ilmu agama terkhusus kepandaian dalam membaca al-Qur'an. Di sisi lain, tradisi ini memberikan dampak hiburan bagi anak-anak karena mendapatkan hadiah berupa kado dan uang dari tamu undangan. Dengan demikian, anak-anak yang belum mengikuti tradisi Katam Kaji tentu akan terpantik dan berkeinginan pula merasakan hal-hal seperti kawan-

\footnotetext{
${ }^{8}$ Anwar, Wali Jorong Pauh, Wawancara Langsung, Pauh 5 November 2015. ${ }^{9}$ Ibid.,
}

kawanya yang lain tersebut. ${ }^{10}$ Hanya saja, dalam konteks ini tidak akan tujuan tradisi Katam Kaji tidak sampai pada pesan substantifnya sebab motivasi mereka hanya sebatas mendapatkan hadiah.

Pernyataan yang serupa denga informan sebelumnya juga disampaikan Yamun Dt. Samiak selaku ninik mamak dan cadiak pandai bahwa Katam Kaji yang dilakukan masyarakat Pauh adalah bentuk dari penerapan nilai-nilai 'Adat Basandi Syara' dan Syara' Basandi Kitabullah, Syara' Mangato Adat Mamakai dalam kehidupan masyarakat Pauh. Sebagai salah satu petinggi adat dalam masyarakat Pauh, ia ingin tegak kokhnya ajaran Islam dalam kehidupan bermasyarakat di Pauh. Oleh karena itu, para ninik mamak sebetulnya berharap dengan adanya tradisi Katam Kaji, nilai-nilai Islam tetap terpatri dalam adat masyarakat Pauh, karena orang yang sudah melakukan Katam Kaji berarti mereka telah memiliki kemampuan untuk membaca al-Qur'an, memahami dan mengkajinya sehingga membuat mereka mudah untuk memahami ajaran agama. ${ }^{11}$

Sejalan dengan itu menurut Syarifuddin Dt. Tumbasa dalam adat Minangkabau ninik mamak adalah orang yang bertanggung jawab untuk membina anak dan kamanakan. Pepatah Minang mengatakan, "anak dipangku kamanakan dibimbing”. Berdasarkan pepatah ini menunjukkan bagaimana fungsi ninik mamak dalam membina dan membimbing anak

\footnotetext{
${ }^{10}$ Rahmi, Peserta Khatam al-Qur'an ke35 MDA Muhammadiyah Ranting Pauh,Wawancara Langsung, 15 November 2015.

${ }^{11}$ Yamun Dt. Samiak, Ninik Mamak, wawancara langsung, 18 November 2015
} 
kemenakan mereka. Dengan adanya Katam Kaji dapat menjadi salah satu metode untuk membina dan membimbing anak kemenakan mereka agar memiliki pribadi yang luhur serta taat bergama. ${ }^{12}$

Sementara golongan cendikiawan di Pauh memahami bahwa Katam Kaji sangat baik dijadikan sebagai metode dalam mendidik anak-anak. Pendidikan yang didapatkan dari Katam Kaji berorientasi pada pendidikan akidah dan akhlak. ${ }^{13}$ Ini tentu akan sangat bermamfaat bagi masyarakat Pauh karena tradisi Katam Kaji dapat menghasilkan generasi yang bermentalkan qur'ani.

Pendidikan agama di daerah Pauh lebih banyak diajarkan di surau, TPA dan MDA. Meskipun ada beberapa Sekolah Dasar tetapi persentase pendidikan agama tidak terlalu besar dibanding dengan pendidikan umum. Maka, mendidik anak-anak di surau, TPA, dan MDA dapat membekali keilmuan agama lebih banyak. Apalagi jika anak tersebut sampai melaksanakan Katam Kaji karena ia adalah simbol bagi yang melaksanakannya bahwa mereka adalah orang yang memiliki pengetahuan agama. ${ }^{14}$

Sementara itu, dari golongan alim ulama juga memandang tradisi Katam Kaji yang dilakukan masyarakat Pauh sebagai syiar agama Islam. Dalam Islam diperintahkan untuk membaca alQur'an, banyak dalil atau landasan

\footnotetext{
${ }^{12}$ Syarifuddin Dt. Tumbasa, Ketua Kerapatan Adat Nagari (KAN) Kamang Mudik, Wawancara Langsung, Kamang 07 November 2015.

${ }^{13}$ Bujang Kaeh Tuangku Samiak, Tokoh Agama dan Terpelajar di Jorong Pauh, Wawancara Langsusng, Pauh 13 November 2015.

$$
{ }^{14} \text { Ibid., }
$$
}

yang membicarakan hal itu. Maka, dengan begitu Katam Kaji pada masyarakat Pauh telah sejalan dengan anjuran Islam untuk mencintai dan membaca al-Qur'an.

Banyak nilai-nilai al-Qur'an yang bisa diperoleh dari Katam Kaji, seperti nilai-nilai persatuan dan kesatuan antara sesama umat Islam, nilai-nilai ibadah di mana ketika acara Katam Kaji banyak orang yang datang untuk menyaksikan dan mendengarkan peserta Katam Kaji membacakan beberapa ayat al-Qur'an. Di sinilah letak nilai ibadahnya, bahwa dalam ajaran Islam, tidak hanya orang yang membaca saja yang mendapatkan pahala, namun orang yang mendengarkannya juga mendapatkan pahala. ${ }^{15}$

Menurut Abdurrahman bahwa dalam tradisi Katam Kaji juga terdapat nilai-nilai akidah di mana dalam ajaran Islam orang yang membaca ayat-ayat Allah akan dilindungi oleh Allah dan diberkati-Nya karena membaca alQur'an merupakan salah satu wujud dari ketaatan seorang hamba pada Penciptanya. Maka dari itu, Katam Kaji dalam pelaksanaanya membaca ayatayat al-Qur'an tentu akan memberi rahmat terhadap makhluk sekelilingnya dan tentunya al-Qur'an benar-benar akan menjadi rahmat untuk seluruh alam. ${ }^{16}$

Dari sekian komentar lapisan masyarakat Pauh tentang Katam Kaji yang telah mereka laksanakan secara turun temurun menunjukan bahwa Katam Kaji memiliki urgensi dan eksistensi yang tinggi, baik itu pada agama ataupun adatistiadat, laki-laki

${ }^{15}$ Abdurrahman, Tokoh Agama Pauh, Wawancara Langsung,Pauh 18 November 2015. 
ataupun wanita serta pada anak-anak ataupun orang dewasa, dan lain sebagainya. Oleh sebab itulah, masyarakat Pauh ingin terus melestarikan Katam Kaji ini karena banyak memiliki nilai-nilai positif dalam kehidupan mereka.

\section{Menilik Simbolisme dalam Tradisi Katam Kaji}

Sebagaimana telah disebutkan sebelumnya bahwa Katam Kaji yang dipahami masyarakat Pauh adalah perayaan untuk memotivasi anak-anak gemar membaca al-Qur'an. Menurut Alif Rila perayaan Katam Kaji masyarakat Pauh adalah haflah untuk memotifasi anak-anak cinta membaca al-Qur'an meskipun para peserta Katam Kaji belum pernah menamatkan bacaan membaca al-Qur'an. ${ }^{17}$ Mukhtar Dt. Mangguang juga mengatakan bahwa peserta Katam Kaji yang selama ini dilaksanakan masyarakat Pauh tidak sampai menamatkan bacaan alQur'an. ${ }^{18}$ Hal yang senada juga diungkapkan Syafrinto bahwa dari segi istilah, Katam Kaji memang berarti telah selesai membaca al-Qur'an sampai tamat. Akan teapi, Katam Kaji yang dilaksanakan masyarakat Pauh adalah salah satu bentuk syiar Islam. Tujuan yang ingin dicapai dari acara tersebut adalah nilai-nilai kebersamaan dan nilai-nilai sosial. ${ }^{19}$

Sudah disebutkan bahwa agama, di samping sebagai sebuah keyakinan,

\footnotetext{
${ }^{17}$ Alif Rila, Guru MDA Muhammadiyah Puah, Wawancara Langsung, Pauh 14 November 2015.

${ }^{18}$ Mukhtar Dt. Mangguang, Tokoh Masyarakat,Wawancara Langsung, Pauh 13 November 2015.

${ }^{19}$ Syafrianto, Juri Katam Kaji MDA Plus

Tigo Kampuang Jorong Pauh keVIII, Wawancara Langsung, Pauh 20 Desember 2015.
}

juga merupakan pranata sosial. Artinya, agama yang dianut melahirkan berbagai perilaku sosial yakni perilaku yang tumbuh dan berkembang dalam sebuah kehidupan bersama. Terkadang perilaku tersebut saling mempengaruhi satu sama lain. Norma dan nilai agama sangat berpengaruh terhadap perilaku sosial. $^{20}$

Katam Kaji yang ditradisikan oleh masyarakat Pauh juga dapat dikatakan sebagai bentuk dari pranata sosial yang terkait dengan agama. Secara sadar atau tidak, Katam Kaji telah mempengaruhi bentuk perilaku masyarakat Pauh secara kolektif ataupun perorangan. Setiap individu akan saling mempengaruhi individu yang lain.

Dalam teori antropologi agama dikatakan bahwa beribadat bersamasama memakai lambang keagamaan telah mempersatukan kelompokkelompok manusia dalam ikatan yang paling erat. Agama memberi lambang kepada manusia, dengan lambanglambang tersebut mereka dapat mengungkapakan hal-hal yang susah untuk diungkapkan. Memiliki kepercayaan yang sama dan mengamalkannya bersama-sama dalam kelompok masyarakat, yaitu kelompok pemeluk amat penting bagi agama. Hanya dengan kebersamaan inilah kepercayaan-kepercayaan tersebut dapat dilestarikan. ${ }^{21}$

Masyarakat Pauh memandang Katam Kaji sebagai ritual keagamaan

${ }^{20}$ Syauthi Ali, Metodologi Penelitian Agama; Pendekatan Teori dan Praktek, (Jakarta: PT. Raja Grafindo Persada, 2002), h. 100 .

${ }^{21}$ Elizabeth K. Nottingham, Agama dan Masyarakat, petrj. Abduk Muis Naharong, (Jakarta: PT. Raja Grafindo Persada, 1996), h. 4. 
yang perlu dilestarikan. Pada konteks inilah tradisi Katam Kaji yang dilakukan masyarakat Pauh lahir sebagai proses budaya yang memadukan ajaran Islam dengan adat Minangkabau. Sebagaimana diketahui bahwa Islam memerintahkan kepada penganutnya untuk mengimani dan mencintai kitab sucinya yakni al-Qur'an. Salah satu bentuknya adalah dengan cara membaca dan menamatkan bacaan al-Qur'an sebagaimana yang diperintahkan Allah dan Rasul-Nya. Namun, perintah membaca dan menamatkan al-Qur'an diresepsi masyarakat Pauh dalam bentuk bentuk dari perayaan. Perayaan tersebut terus dilestarikan dan dalam perkembangannya dipengaruhi unsur budaya lokal. Unsur-unsur itu tercermin dari atribut dan simbol yang digunak. Setiap simbol menyimpan nilai dan makna tersendiri bagi masyarakat.

Simbolisasi makna dalam tradisi Katam Kaji masyarakat Pauh dapat dikelompokkan sebagai berikut:

\section{Makna Simbolik}

Dalam pelaksanaan tradisi Katam Kaji terdapat makna-makan yang diungkapkan masyarakat melalui sistem simbol. Salah satunya dapat diamati dari pakaian kebesaran yang digunakan peserta Katam Kaji, gelar adat dan penggunaan mushaf alQur'an. Semua ini dimaknai sebagai simbolisasi wujud ketaatan kepada agama dan budaya setempat. Untuk lebih jelasnya makna simbolik yang digunakan dalam pelaksanaan Katam Kajiadalah :

\section{a. Pakaian Kebesaran (Gamis)}

Pakaian kebesaran peserta Katam Kaji adalah pakaian gamis yang mirip pakaian orang Arab. Pakaian tersebut menjadi pakaian wajib yang harus digunakan peserta Khatam al-Qur'am ketika perayaan. Oleh karena Katam Kaji merupakan fenomena sosial yang terkait dengan agama Islam maka pakaian pesertanya juga diidentikkan dengan pakaian Islami. Dalam hal ini pakain Islami itu diidentikkan dengan pakaian yang berasal dari tanah Arab, tempat agama Islam lahir dan berkembang pertama kali. Pakaian tersebut tidak boleh diganti dengan pakaian lainnya. Sebagaimana ditegaskan Yadi Dt. Ruhun Basa bahwa gamis adalah pakaian yang berasal dari Arab. Rasulullah adalah orang Arab yang juga memakai gamis. Gamis biasanya dipakai oleh para alim ulama di Pauh. Gamis adalah pakaian khusus yang mencerminkan keilmuan orang yang memakainya. Dengan demikian masyarakat menjadikan gamis sebagai pakaian kebesaran dalam Katam Kaji menjadi posisi yang penting. Kemudian tatkala diaraknya peserta Katam Kaji keliling kampung dengan berpakaian gamis untuk memberitahukan kepada masyarakat bahwa peserta Katam Kaji adalah orang-orang yang sudah belajar agama Islam dan mestinya setelah perayaan selesai mereka dapat menjadi teladan bagi masyarakat di sekitarnya. $^{22}$

Penggunaan gamis sebagai pakaian kebesaran dan dipandang sebagai upaya mencontoh pakaian Nabi Muhammad SAW merupakan bentuk masyarakat meneladani

22 Yadi Dt. Ruhun Basa, Mantan Pegawai Camat Kamang Magek, Wawancara Langsung, 18 November 2015. 
sunah Rasul SAW dalam berpakaian. Pada konteks ini, terlah terjadi upaya penerjemahan sunah dalam bentuk praksis. Oleh karena itu, apa yang dilakukan masyarakat Pauh telah membuktikan adanya proses pembumian sunah Rasul SAW, atau dalam istilah lain yakni living traditions (living sunah/ living hadis).

\section{b. Gelar Adat}

Sudah menjadi kebiasaan pada keseharian masyarakat Pauh memanggil seseorang dengan gelar adat. Ada tiga bentuk pemberian gelar adat kepeada seseorang. Pertama, gelar yang diberikan ketika batagak panghulu. Kedua, gelar yang diberikan ketika akan menikah. Ketiga, gelar yang diberikan ketika Katam Kaji. Gelar tersebut hanya diberikan kepada kaum laki-laki. Hal ini dikarenakan dalam beberapa aspek kehidupan di Minangkabau kaum lelaki memiliki peran yang dominan.

Jenis gelar yang ketiga di atas merupakan gelar yang pertama kali didapatkan seseorang dalam kehidupan sosialnya di daerah Pauh. Gelar tersebut antara lain seperti: Tuangku, Malin, Kari, Labai dan Sutan. Gela-gelar ini pada dasarnya melambangkan karakter orangnya. Selain itu, gelar tersebut juga mencerminkan bagaimana kapasitas ilmu agama mereka. ${ }^{23}$

\section{c. Mushaf Al-Qur'an}

Sebagaimana pengamatan penulis pada acara Katam Kaji masyarakat Pauh, dalam rombongan

\footnotetext{
${ }^{23}$ Syahrial Dt. Kayo Niniak Mamak. Wawancara Langsung, 15 November 2015.
}

pawai terdapat dua orang perempuan membawa al-Qur'an pada barisan paling depan. ${ }^{24}$ Menurut Alif Rila, prosesi ini mengandung makna sebagai berikut: Sabana nyo dasar hukum nyo ndak ada gai do, tu hanyo sabagai tando bahaso awak malakukan Katam Kaji, mangkonyo dilatak-an di muko. Ba a ndak ndak di tangah atau di balakang, karano al-Qur'an nilainyo tinggi. ${ }^{25}$

Sebenarnya tidak ada dasar hukumnya. Itu hanya tanda bahwa sedang diadakan perayaan Katam Kaji, maka-nya diletakan di depan. Lalu, kenapa tidak di tengah atau di belakang. Karena, al-Qur'an memiliki nilai yang tinggi dan harus dijadikan pedoman dalam hidup.

Fenomena di atas menunjukkan bagaimana al-Qur'an diperlakukan dan oleh masyarakat Pauh. Secara simbolik, perlakukan seperti itu menjadi simbol bahwa alQur'an harus dijadikan imam dalam kehidupan sehari hari. Dalam melakukan hal apapun, al-Qur'an mestinya menjadi acuan utama.

\section{Makna Praktik atau Esensi}

a. Nilai Silaturrahmi

$$
\begin{aligned}
& \text { Perayaan Katam Kaji } \\
& \text { menyimpan makna-makna yang } \\
& \text { memiliki nilai-nilai religius yang } \\
& \text { berlandaskan pada ajaran agama. }
\end{aligned}
$$

${ }^{24}$ Hasil observasi lapangan pada acara Katam Kaji MDA Plus Tigo Kampung Jorong Pauh pada 20 Desember 2015.

${ }^{25}$ Alif Rila, Guru MDA Muhammadiyah Pauh, Wawancara Langsung, Pauh 14 November 2015. 
Katam Kaji bagi masyarakat Pauh merupakan alek kampung (baralek gadang) yang diikuti oleh setiap lapisan masyarakatnya. Prosesi tradisi Katam Kaji dari awal hingga akhir pelaksanaannya yang melibatkan seluruh masyarakat Pauh. Dalam pelaksaan tersebut terajalin silaturrahmi. Karena, seluruh masyarakat berpartisipasi di dalamnya, mulai dari panitia, peserta, dan masyarakat luas.

Menurut Alif Rila bahwa Katam Kaji merupakan adat dan kebiasaan yang baik untuk dilestarikan. Banyak nilai-nilai alQur'an yang tersimpan dalam acara Katam Kaji ini. Di antaranya adalah memberikan motivasi pada anakanak, membumikan membaca alQur'an dan terdapat juga nilai-nilai persaudaraan. Banyak ayat yang mendorong masyarakat untuk meningkatkan rasa persaudaraan. Misalnya, dalam surat Ali Imran ayat 103 yang memerintahkan bahwa "janganlah kalian bercerai berai". Selain itu, terdapat juga perintah untuk menjaga nilai persaudaraan dengan cara berkumpul bersama-sama, seperti yang hadis tentang al-Jam'atu Rahmah. $^{26}$

Masyarakat berbondongbondong melihat perayaan Katam Kaji. Di saat inilah terjadi interaksi sosial yang lebih intens antara sesama mereka. Kalau pada hari lain mereka lebih disibukan dengan pekerjaan sehari-hari, maka pada momentum Katam Kaji mereka bisa

\footnotetext{
${ }^{26}$ Alif Rila, Guru MDA Muhammadiyah Puah, Wawancara Langsung, 14 November 2015.
}

saling berkomunikasi lebih lama dan saling bersilaturahmi. ${ }^{27}$

Selain bisa berkumpul bersama pada acara Katam Kaji, mereka juga dipertemukan dalam acara baralek Katam Kaji yang dilaksanakan pesertanya di rumah mereka. Sirajul Munir salah seorang tokoh agama di daerah itu menuturkan bahwa setiap orang tua yang anaknya menjadi peserta Katam Kaji pasti melaksanakan syukuran dalam bentuk alek atau pesta. Para sanak famili, tetangga dan orang kampung diundang untuk datang menghadiri pesta tersebut. Setiap orang yang datang ke rumah membawa amplop berisi uang, kado, dan sejenisnya sebagai hadiah untuk anak yang ikut Katam Kaji. Bentuk pesta seperti ini juga didasarkan pada ayat al-Qur'an, seperti disebutkan dalam surat al-Dhuha ayat $11 .^{28}$

Dengan adanya alek Katam Kaji ini juga memberikan kesempatan pada para tamu undangan yang terdiri dari famili, orang kampung dan para pemuda serta remaja dapat bersilaturrahmi dengan tuan rumah dan antara sesama mereka.

Apabila dilihat dalam alQur'an terkait dengan ayat yang berbicara mengenai silaturrahmi bahwa pada dasarnya Allah SWT berfirman dalam surat al-Ra'du ayat 21 :

${ }^{27}$ Ibid., Sirajul Munir, Tokoh Agama, Wawancara Langsung, 18 November 2015. Terkait ayat yang dimaksud informan ini yaitu:

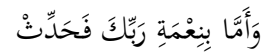

Artinya: "dan terhadap nikmat Tuhanmu, Maka hendak-lah kamu siarkan".(QS.AlDhuha:11) 


$$
\begin{aligned}
& \text { وَالَّذِينَ يَصِلُونَ مَا أَمَرَ اللَّهُ بِِه أَنْ يُوصَلَ }
\end{aligned}
$$

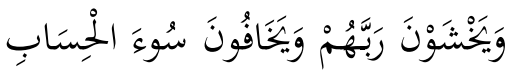

Artinya:" orang-orang yang menghubungkan apa-apa yang Allah perintahkan supaya dihubungkan, dan mereka takut kepada Tuhannya dan takut kepada hisab yang buruk”. (QS. Al-Ra'du: 21)

Menurut M. Quraish Shihab ayat ini menjelaskan tentang ciri-ciri dan sifat Ulul albab, di mana salah satu ciri dan sifatnya adalah orangorang yang senantiasa menghubungkan apa-apa yang Allah perintahkan supaya digabungkan seperti seperti silaturrahmi. ${ }^{29}$

Oleh sebab itu, penulis ingin menegaskan bahwa tradisi Katam $K a j i$ ingin memberikan pesan tentang perlunya membangun hubungan komunikasi masyarakat yang baik. Pesan itu diciptakan melalui kerjasama, komunikasi, dan interaksi yang terbangun dalam perhelatan tradisi ini. Cara ini secara tidak langsung memperlihatkan peranan budaya agama dalam mempererat dan merawat silaturahmi.

\section{b. Nilai-nilai Ukhwah Islamiyah}

Katam Kaji sebagai fenomena sosial-agama juga memiliki nilai semangat ukhwah islamiyah. Menurut Abdurrahman, bahwa Katam Kaji adalah tradisi yang dari dahulu sampai sekarang masih dipegang erat oleh masyarakat Pauh.

${ }^{29}$ M. Quraish Shihab, Tafsir alMishbah; Pesan, Kesan dan Keserasian alQur'an, (Jakarta: Lentera Hati, 2002), Vol. 06, h. 590 .
Acara Katam Kaji mustahil akan terlaksana jika masyarakatnya tidak kompak. Untuk mempersiapkan acara Katam Kaji masyarakat Pauh saling bantu membantu dan bergotong royong agar acara tersebut terlaksana. Dengan demikian rasa persaudaraan antara sesama mereka akan semakin terasa, terlebih lagi dengan adanya sesi makan bersama di talam (piring besar) untuk seluruh orang kampung yang dipersiapkan oleh panitia ketika acara Katam Kaji. Tradisi seperti ini tentu akan menambah rasa persatuan di kalangan masyarakat. $^{30}$

Islam adalah agama yang menolak adanya diskriminasi dalam kehidupan manusia. Oleh sebab itu, Islam selalu menjunjung tinggi nilai-nilai persatuan dan kesatuan. Salah satu ajaran Islam yang berbicara tentang hal itu ialah seperti yang tertera dalam al-Qur'an yaitu surat al-Hujurat ayat 10 :

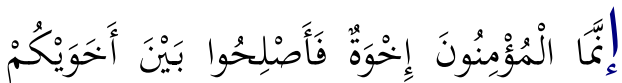

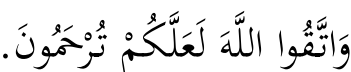

Artinya:"sesungguhnya orangorang ber-iman itu bersaudara. Maka, damaikanlah antara saudaramu itu dan takutlah terhadap Allah, supaya kamu mendapat rahmat. (QS.Al-

\section{Hujurat: 10)}

M. Quraish Shihab ketika menafsirkan ayat di atas mengatakan bahwa ayat ini mengisyaratkan dengan sangat jelas bahwa persatuan dan kesatuan serta

${ }^{30}$ Abdurrahman, Tokoh Agama Pauh, Wawancara Langsung, Pauh 18 November 2015. 
hubungan harmonis antar anggota masyarakat kecil atau besar akan melahirkan limpahan rahmat bagi mereka semua. ${ }^{31}$ Selain ayat alQur'an juga terdapat sabda Rasulullah SAW yang senada dengan ayat di atas yaitu:

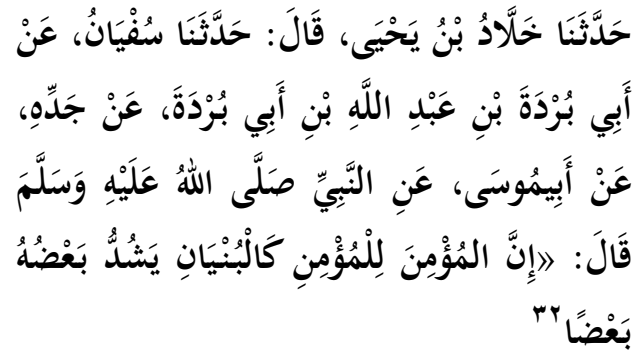

Artinya: 'Khallad bin Yahya berkata,memberitahukan pada kami Sufyan menyampaikan pada kami Abu Burdah bin 'Abdillah bin Abi Burdah dari kakeknya dari Abi Musa bahwa Nabi Muhammad SAW pernah bersabda, yaitu sesungguhnya orang-orang mukmin itu seperti sebuah bangunan yang saling menguatkan satu sama lain.",

\section{(H.R. Al-Bukhari)}

Terkait dengan tradisi Katam Kaji pada masyarakat Pauh bahwa ini merupakan bentuk realisasi dari nilai-nilai ukhwah yang dimaksudkan Allah dalam al-Qur'an dalam kehidupan umat. Hal itu sejalan dengan pandanganpandangan para tokoh tentang tradisi ini.

\section{c. Nilai-nilai Edukasi}

Proses tradisi Katam Kaji juga tidak bisa terlepas dari tradisi oral atau proses membaca. Katam Kaji merupakan langkah awal bagi

\footnotetext{
${ }^{31}$ M. Quraish Shihab, op cit., Vol. 13, h. 249.

${ }^{32}$ H.R. al-Bukhariy (CD Maktabah alSyamilah : Shahih Bukhariy, Bab Tasybiikal Ashabi'iy Fil Masjid wa Ghairih, hadis 103).
}

pesertanya untuk memahami teksteks agama secara mendalam. Sebagaimana pendapat Bujang Kaeh Tuangku Samiak tentang hal ini :

Katam Kaji bisa dikecekan tamaik kaji untuak anak-anak nan mangaji. Inyo indak kabisa ikut Katam Kaji kalau alun pandai mambaco al-Qur'an. Jadi urang nan Katam Kaji tu yo urang nan lah tapiliah. Tapi nan paralu diingek tamat kaji tu dak bararti lah salasai mangaji do. Indak. Tamat kaji tu adolah awal untuk bisa baraja agamo. Kalau lah bisa mambaco ansua ansua mamahami maknanyo, sudah tu baru diansua maamaan. Tapi di urang awak nan itu nan ditinggaan. Kalau lah siap Katam Kaji dak ado se pai $k a$ surau lai. Urang gaek no indak lo manyuruahan. Iko nan harus wak pelokan basamo. ${ }^{33}$

Katam Kaji dapat dikatakan selesai mengaji bagianank-anak yang belajar mengaji. Ia tidak akan bisa ikut "Katam Kaji jia belum bisa membaca al-Qur'an. Jadi orang yang Katam Kaji tersebut adalah orang yang terpilih. Tapi yang perlu diketahui Katam Kaji itu bukan berarti telah selesai belajar mengaji. Tidak. Katam Kaji itu adalah awal untuk mempelajari ajaran agama. Jika telah bisa membaca al-Qur'an maka cobalah untuk mempelajari makna ayatnya, lalu cobalah untuk mengamalkannya. Tapi bagimasyarakat kita hal itu

${ }^{33}$ Bujang Kaeh Tuangku Sami', Tokoh Agama dan Terpelajar di Jorong Pauh, Wawancara Langsusng, Pauh 13 November 2015. 
yang telah dilupakan. Jika telah ikut Katam Kaji tidak pernah lagi datang ke surau. Orang tua mereka-pun tidak memerintahkan untuk itu. Hal ini yang harus diperbaiki bersama".

Dari pernyataan Bujang Kaeh di atas dapat dipahami bahwa Katam Kaji dapat menunjang motivasi belajar. Anak-anak dituntut untuk bisa membaca kitab suci agama mereka. Katam Kaji menjadi sarana dalam memberikan pendidikan agama di usia dini pada anak-anak. Hal ini juga sejalan dengan alQur'an, di mana dalam al-Qur'an juga terdapat nilai-nilai pendidikan agama pada usia dini bagi seorang anak. Salah satunya adalah kisah Luqman memberi nasehat kepada anaknya yang terdapat pada surat Luqman ayat 12-19. Dalam tafsir Fii Zhilali Al-Qur'an yang ditulis Sayyid Quthb dijelaskan bahwa ayat ini merupakan kisah yang penuh dengan hikmah dan kebijaksanaan serta menjelaskan nilai-nilai apa yang seharusnya ditanamkan kepada anak. $^{34}$ Dengan kata lain, tradisi Katam Kaji adalah media edukasi bagi masyarakat Pauh untuk mengintenalisasikan ayat-ayat tentang penanaman nilai-nilai spirittual bagi anak-anak sejak usia dini.

\section{d. Etos Kerja}

Bagi masyarakat Pauh selain makna silaturrahmi, pemersatu umat, dan pendidikan. Katam Kaji juga memiliki nilai motivasi untuk

34 Sayyid Quthb, Tafsir Fii Zhilalil Qur'an, (Jakarta: Gema Insani, 2004), h. 173177. bekerja dengan sunguh-sungguh. Sebagaimana menurut Syafrianto: "bagi urang awak mangalua-an pitih untuak basidakah kini ko ha, mungkin labiah barek dari pado maagiahan iyuran untuak anak no Katam Kaji. Mode tu bana antusias orang gaek ka anak nyo buliah bisa ikuik Katam Kaji.Bagi urang gaek pitih sajuta limo ratuh tu untuak iyuran Katam Kaji tu bisa diusahokannyo mandapekan, bahkan jauh hari sabalun anak nyo ka Katam Kaji lah disadioan sabalunno.Katam Kaji bisa mandorong urang untuk mancari pitih. 'Ko anak wak ka Katam Kaji lai ko', ha jadi diansua-ansua malungguakkan pitih untuak baiyua. Mode tu lah, pitih sajuta limo ratuh tu dak terlalu gadang bagi urang gaek nan ka mangKatam Kajian anak no". 35

"Bagi masyarakat kita memberikan uang untuk bersedekah mungkin lebih berat dari pada memberikan iyuran untuk Katam Kaji.Seperti itulah antusias orang tua kepada anaknya agar bisa ikut Katam Kaji. Bagi orang tua uang sebesar satu juta lima ratus bisa diusahakan untuk mencarinya, bahkan jauh sebelum anak mereka akan ikut Katam Kaji sudah dipersiapkan. Jadi, dengan adanya Katam Kaji bisa mendorong seseorang untuk berusaha. Ini anak kita akan

35 Syafrianto, Juri Katam Kaji MDA Plus Tigo Kampuang Jorong Pauh keVIII,Wawancara Langsung,Pauh 20 Desember 2015. 
ikut Katam Kaji, ha mulai lah mengumpulkan uang untuk iyurannya. Seperti itulah.Uang satu juta lima ratus itu tidak terlalu besar bagi mereka untuk mengeluarkan uang iyuran Katam Kaji”.

Seorang muslim meyakini bahwa Islam adalah agama yang sempurna. Kesempurnaan Islam sesuai dengan fithrah Allah, di mana adanya keseimbangan antara aspek duniawi dan ukhrawi. Islam tidak hanya mendorong umatnya untuk mengejar kehidupan akhirat semata atau sebalinya dunia semata. Jika kita lihat dalam ibadah yang dilakukan dalam Islam tidak bisa dilepaskan dari nilai ekonomi seperti zakat, shadaqah, waqaf, bahkan untuk shalatpun seseorang mesti memiliki pakainan yang menutup aurat dan lain sebaginya. Ini tentu mengindikasikan bahwa Islam mendorong umatnya untuk bekerja agar memiliki ekonomi yang mapan sehingga memudahkan ia untuk beribadah kepada Allah. Nilai-nilai inilah yang terdapat dalam surat al-Qashash ayat 77 yaitu :

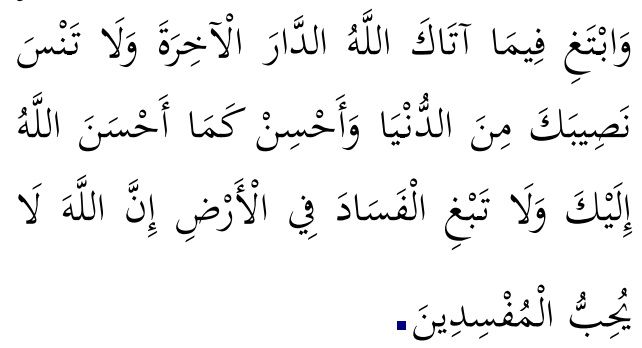

Artinya: "carilah pada apa yang telah dianugerahkan Allah kepadamu (kebahagiaan) negeri akhirat, dan janganlah kamu melupakan bahagianmu dari (kenikmatan) duniawi dan berbuat baiklah (kepada orang lain) sebagaimana Allah telah berbuat baik, kepadamu, dan janganlah kamu berbuat kerusakan di (muka) bumi. Sesungguhnya Allah tidak menyukai orang-orang yang berbuat kerusakan. (QS. Al-Qashash: 77)

Ayat ini menggambarkan keseimbangan manhaj Ilahi yang lurus. Allah menciptakan kenimatan duniawi tidak hanya untuk dinikmati oleh manusia, tetapi agar mereka berusaha menyimpan dan menghasilkannya. Menyimpan dan menghasilkannya di sini adalah agar manusia bisa memelihara kenikmatan duniawi dan mendapatkannya. Berkerja termasuk cara manusia menyimpan dan menghasilkan kenimatan duniawi agar kehidupan ini terus berlanjut. ${ }^{36}$

Al-Qur'an selain berfungsi sebagai bacaan ia juga merupakan petunjuk dan pedoman bagi manusia, sebagaimana yang terdapat dalam surat al-Jin ayat 1-2 yaitu:

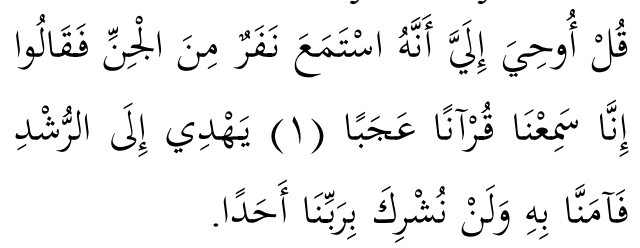

Artinya: 'Katakanlah hai Muhammad: "Telah diwahyukan kepada-mu bahwasanya: telah mendengarkan sekumpulan jin (akan al-Quran), lalu mereka berkata: Sesungguh-nya Kami telah mendengarkan Al- Quran yang menakjubkan. (yang) Memberi petunjuk kapada jalan yang benar, lalu Kami ber-iman kepadanya.dan Kami sekali-kali tidak akan mempersekutukan seseorangpun dengan Tuhan Kami"' (QS. Al-Jin: 1-2).

${ }^{36}$ Sayyid Quthb, op cit., Jil. 9, h. 72. 
Menurut Farid Esack pada ayat ini terdapat paling tidak dua fungsi utama al-Qur'an dalam kehidupan umat Islam yakni sebagai bacaan dan petunjuk. ${ }^{37}$ Melalui Tradisi Katam Kaji, masyarakat Pauh berusaha untuk menanamkan rasa cinta kepada al-Qur'an dan memotivasi untuk membaca serta mempelajarinya. Di sisi lain, sebenarnya masyarakat Pauh telah mengfungsikan al-Qur'an sebagai petunjuk dalam kehidupan mereka. Dengan adanya tradisi Katam Kaji nilai-nilai tentang silaturrahmi, ukhwah islamiyah, pendidikan dan semangat etos kerja yang terdapat dalam ayat al-Qur'an tidak lagi berada dalam lembaran mushaf melainkan telah membumi dalam kehidupan masyarakat Pauh.

\section{Kesimpulan dan Rekomendasi}

Sebagai sebuah kesimpulan penulis ingin mengatakan bahwa Katam Kaji merupakan tradisi islami. Di dalamnya mengandung nilai-nilai kebajikan yang diekspresikan melalui simbol dan pemaknaan yang mendalam terhadap esensi acaranya. Adapun simbol itu disematkan pada pakaian, gelar adat, dan mushaf al-Qur'an. Sedangkan makna esensinya adalah sebagai sarana merajut silaturahmi, memperkokoh ikatan persaudaraan sesama umat Islam dalam anggota masyarakat, sebagai sarana dalam memotivasi masyarakat terutama anak-anak untuk membaca dan mempelajari al-Qur'an, dan meningkatkan etos kerja sebab dalam prosesi tersebut memerlukan dalan untuk pelaksanaan perhelatan. Akan

37 Farid Esack, Samudera Al-Qur'an, pterj. Nuril Hidayah, (Jogjakarta: DIVA Press, 2007), h. 43. tetapi, yang jauh lebih penting dari itu semua adalah bahwa Katam Kaja menjadi salah satu pilihan dalam memotivasi dan mensugesti anak-anak untuk belajar al-Qur'an secara tradisionalis. Adapun rekomendasi yaitu menganjurkan bagi yang ingin meneliti Katam Kaji untuk mengkaji bagaimana tradisi ini dilihat dengan perspektif dan metodologi yang berbeda, seperti melihat keterkaitannya dengan daerah-daerah lain di Sumatera Barat. Selanjutnya kepada para pihak di daerah Pauh Kamang Mudiak semestinya tradisi baik ini dijaga dan dirawat dalam bingkai keislaman dan kebudayaan. Seandainya hal ini tidak dilakukan maka dikhawatirkan akan terjadi kesalahpahaman yang menyebabkan tradisi ini ditinggalkan sehingga nilai-niliai kebajikan yang tersimpan di dalamnya luntur dan hilang.

\section{Daftar Kepustakaan}

\section{A. Buku dan Jurnal}

Ali, Syauthi. Metodologi Penelitian Agama; Pendekatan Teori dan Praktek. Jakarta: PT. Raja Grafindo Persada. 2002.

Al-Bukhary, Muhammad bin Ismail. dalam Shahih al-Bukhariy kitab Fadhail al-Qur'an Nomor. 4639.

Esack, Farid Samudera Al-Qur'an. pterj. Nuril Hidayah. Jogjakarta: DIVA Press. 2007.

H.R. al-Bukhariy (CD Maktabah alSyamilah: Shahih Bukhariy, Bab Tasybiikal Ashabi'iy Fil Masjid wa Ghairih. hadis 103. 
Mundzir, Chaerul. "Nilai-Nilai Sosial dalam Tradisi Mappenre Temme' di Kecamatan Tenete Kabupaten Barru" Jurnal Rihlah. Vol. I. No. 2 Tahun. 2014.

Nottingham, Elizabeth K. Agama dan Masyarakat. Petrj. Abduk Muis Naharong. Jakarta: PT. Raja Grafindo Persada. 1996.

Quthb, Sayyid. Tafsir Fii Zhilalil Qur'an. Jakarta: Gema Insani. 2004.

Shihab, M. Quraish Tafsir al-Mishbah; Pesan, Kesan dan Keserasian alQur'an. Jakarta: Lentera Hati, 2002.

B. Wawancara, Observasi, dan Dokumentasi

Abdurrahman. Tokoh Agama Pauh, Wawancara Langsung.Pauh 18 November 2015.

Ahmad Latif Dt. Samiak. Niniak Mamak Jorong Pauh. Wawancara Langsung. Pauh 20 Desember 2015.

Alif Rila. Guru MDA Muhammadiyah Puah. Wawancara Langsung. Pauh 14 November 2015.

Anwar. Wali Jorong Pauh. Wawancara Langsung. Pauh 5 November 2015.

Bardas Samnil. Imam Mesjid Jami' Pauh. Wawancara Langsung, Pauh 13 November 2015.

Bujang Kaeh Tuangku Samiak. Tokoh Agama dan Terpelajar di Jorong Pauh. Wawancara Langsusng. Pauh 13 November 2015.
Mukhtar Dt. Mangguang. Tokoh Masyarakat. Wawancara Langsung. Pauh 13 November 2015.

Rahmi. Peserta Khatam al-Qur'an ke35 MDA Muhammadiyah Ranting Pauh.Wawancara Langsung. 15 November 2015.

Sirajul Munir. Tokoh Agama. Wawancara Langsung. 18 November 2015.

Syafrianto. Juri Katam Kaji MDA Plus Tigo Kampuang Jorong Pauh keVIII. Wawancara Langsung. Pauh 20 Desember 2015.

Syahrial Dt. Kayo. Niniak Mamak. Wawancara Langsung. 15 November 2015.

Syarifuddin Dt. Tumbasa. Ketua Kerapatan Adat Nagari (KAN) Kamang Mudik. Wawancara Langsung. Kamang 07 November 2015.

Yadi Dt. Ruhun Basa. Mantan Pegawai Camat Kamang Magek. Wawancara Langsung. 18 November 2015.

Yamun Dt. Samiak. Ninik Mamak. Wawancara Langsung. 18 November 2015. 
62 Jurnal Ulunnuha Vol. 8 No.1/Juni 2019 